\title{
ENVIRONMENTAL EDUCATION IN THE TEACHING OF BIOLOGY IN SCHOOLS OF POMBAL (PB, BRAZIL)
}

\author{
Edevaldo da Silva ${ }^{1}$ \\ Habyhabanne Maia de Oliveira ${ }^{2}$ \\ Alba Luciana Ramos Nascimento ${ }^{3}$
}

\begin{abstract}
Current research evaluates the teaching of environmental themes in Biology and in other disciplines in high schools in the town of Pombal, Paraíba, Brazil. Students' knowledge on environmental themes is also assessed. Ninety students were interviewed through a questionnaire featuring nine items structured on the Likert's scale. Students tended to perceive Biology as a discipline which best explains environmental themes. They showed to be greatly informed on Environmental preservation and Solid wastes and recycling. On the other hand, they knew less on the Harmonious relationship with plants. Significant variation in knowledge was detected between genders with regard to environmental themes. In fact, males were better informed. Results show the need to insert environmental themes within a continuous and interdisciplinary planning.
\end{abstract}

Keywords: Environment; Students; Transdisciplinary.

Resumo: Essa pesquisa avaliou o ensino de temas ambientais, na Biologia e em outras disciplinas, no ensino médio de escolas da cidade de Pombal, Paraíba. Além de avaliar os conhecimentos de seus discentes quanto a esses temas. Foram entrevistados 90 alunos com a aplicação de um questionário, com nove (09) itens estruturados no modelo da escala de Likert. Os alunos tenderam a perceber a Biologia como a disciplina que melhor ensinaria esses temas ambientais e, afirmaram conhecer mais sobre temas relacionados a Preservação ambiental e Resíduos sólidos e reciclagem. Por outro lado, souberam menos sobre a Relação harmoniosa com as plantas. Houve variação significativa no conhecimento entre os gêneros para três temas ambientais, onde, o gênero masculino apresentou maior conhecimento. Os resultados indicam a necessidade da inserção de temais ambientais de forma planejada, contínua e interdisciplinar.

Palavras-chave: Ambiente; Alunos; Transdisciplinar.

${ }^{1}$ Universidade Federal de Campina Grande. E-mail: edevaldo@cstr.ufcg.edu.br.

2 Universidade Federal de Campina Grande. E-mail: haby habanne@hotmail.com.

3 Universidade Federal de Campina Grande. E-mail: alba.cienciasbiologicas@gmail.com.

Revbea, São Paulo, V. 11, No 1: 12-24, 2016. 


\section{Introduction}

The Brazilian educational system is constantly revealing that important changes have occurred during the last decades and they are still occurring. Although significant modifications have occurred, deeper changes are required with regard to the aims and contents in the Biology curriculum (KRASILCHIK, 2008).

In the case of Biology, changes are related to students' teachinglearning conditions. In fact, Biology should be taught so that it may contribute towards the construction of scientific knowledge and the formation of citizens to participate actively and critically in the social life of their country. According to Soares (2004, p. 83): "Current legal arrangement of Brazilian society attributes to the school the role of preparing future generations to participate actively and critically in the social life of the country through the acquisition of knowledge and attitudes".

Innovatory teaching practices affect significantly the cognitive performance of the students since they favor learning and make scientific concepts, especially Biological ones, more accessible for students to understand.

Luckesi (1999) reports that if all teachers develop proficiently their professional activities, great strides in growth conditions will be given to children, young people and adults. Within urgent needs in the Biology curriculum, there is the requirement for teachers to include Environmental Education as a recurring and transversal theme in their lessons.

Since environmental degradation is currently one on the great concerns for governments and society, activities of an educational modality should be developed for sustainable development so that the permanence of natural resources in exactly the same conditions will be guaranteed for future generations on Earth.

However, Environmental Education develops slowly and with difficulty since it needs deep changes (SAUVÉ, 2005). It must develop the capacities of human beings for a new mode of relationship and for social and environmentally correct actions, by collaborating in the solutions of current environmental problems (ARAUJO; FRANÇA, 2013).

The relationship between education and the environment is highly relevant since Education is the mediating element in all human social relationships (IARED; OLIVEIRA, 2011).

The new pedagogical proposal in the Brazilian Curricular Parameters (PCNs) enhanced environmental issues, dealing with local problems and suggesting ways of introducing Environmental Education in the different curricula. According to the PCNs, Environmental Education is a transversal theme and should be analyzed at all grades and in all disciplines by inserting several environmental themes (BRASIL, 1998). 
Environmental themes have been gradually inserted at different levels of teaching within Brazilian schooling and have broadened in proportion to the social insertion of the environmental issue. Several research works have discussed the manner Environmental Education has been dealt with in the classroom. The above reveals that there is concern with regard to its application (IARED; OLIVEIRA, 2011). Consequently, its practice has been widely employed in the Brazilian teaching systems (TRAJBER; MENDONÇA, 2006).

On the other hand, research has also shown that most activities in schools are still fledging and linked to some items only; they lack continuity and theoretical and methodological knowledge (CARVALHO, 1989; BENETTI, 1998). Further, lack of resources in the schools makes difficult its insertion in the classroom (BORGES; ARANHA; SABINO, 2010).

Current research evaluates the teaching of the theme Environmental Education in Biology and other sciences in the secondary schools of Pombal, Paraíba, Brazil. It also verifies knowledge of students with regard to these themes and possible differences on the subject between genders.

\section{Metodology}

\section{Population and Sampling}

Current exploratory, quantitative and descriptive research was undertaken in 2013 with students from two government-run secondary schools in the town of Pombal, Paraíba, Brazil.

Sample size followed Rocha (1997), with Equation 1, in which $\mathrm{n}=$ number of samples; $\mathrm{N}=$ is the total number of students in the secondary school; $3.841=$ constant rate from chi square; $0.25=$ maximum variance for standard deviation 0.5 . Standard error was $10 \%$, with a sample population of 90 interviewed students.

$$
n=\frac{3.841 \cdot N \cdot 0.25}{\left\{(0.1)^{2}(N-1)+3.841 .0 .25\right\}} \quad \text { Equation } 1
$$

\section{Data collection instrument}

Data were collected by a structured questionnaire which collected information on nine current environmental themes (Table 1), coupled to classification variables such as gender and age. Questions were prepared according to the Likert Scale model, with five answer levels. Students responded for each environmental theme with regard to (1) Biology's contribution in teaching; (2) the contribution of other disciplines (Chemistry, Physics, History, Geography, Mathematics, Portuguese) in teaching; and (3) the student's knowledge level on the theme. 
Table 1: Questionnaire applied to interviewees.

\begin{tabular}{|c|c|c|c|c|c|c|}
\hline $\begin{array}{l}\text { Environmental } \\
\text { themes }\end{array}$ & $\begin{array}{c}\text { Discipline/ } \\
\text { Knowledge } \\
\text { Level }^{*}\end{array}$ & 은 & 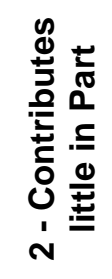 & 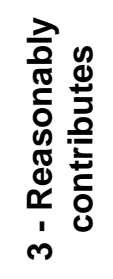 & 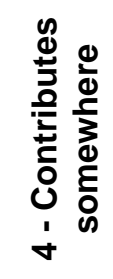 & 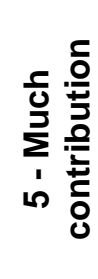 \\
\hline \multirow{3}{*}{ Water pollution } & Biology & ( ) & ( ) & ( ) & () & ( ) \\
\hline & Ohers disciplines & ( ) & ( ) & ( ) & ( ) & ( ) \\
\hline & Knowledge & $(1)$ & $(1)$ & ( ) & $(1)$ & ( ) \\
\hline \multirow{3}{*}{ Soil pollution } & Biology & ( ) & ( ) & ( ) & ( ) & ( ) \\
\hline & Ohers disciplines & ( ) & ( ) & ( ) & ( ) & ( ) \\
\hline & Knowledge & $(1)$ & ( ) & ( ) & ( ) & () \\
\hline \multirow{3}{*}{ Air pollution } & Biology & ( ) & ( ) & ( ) & ( ) & ( ) \\
\hline & Ohers disciplines & ( ) & ( ) & ( ) & ( ) & ( ) \\
\hline & Knowledge & () & ( ) & ( ) & () & () \\
\hline \multirow{3}{*}{ Contaminants } & Biology & ( ) & ( ) & ( ) & ( ) & ( ) \\
\hline & Ohers disciplines & ( ) & ( ) & ( ) & ( ) & ( ) \\
\hline & Knowledge & ( ) & ( ) & ( ) & ( ) & ( ) \\
\hline \multirow{3}{*}{$\begin{array}{l}\text { Environmental } \\
\text { preservation }\end{array}$} & Biology & ( ) & ( ) & ( ) & ( ) & ( ) \\
\hline & Ohers disciplines & ( ) & ( ) & ( ) & ( ) & ( ) \\
\hline & Knowledge & $(1)$ & ( ) & $(1)$ & ( ) & () \\
\hline \multirow{3}{*}{$\begin{array}{l}\text { Solid waste - pollution } \\
\text { and recycling }\end{array}$} & Biology & ( ) & ( ) & ( ) & ( ) & ( ) \\
\hline & Ohers disciplines & ( ) & ( ) & ( ) & ( ) & ( ) \\
\hline & Knowledge & () & ( ) & ( ) & ( ) & $(1)$ \\
\hline \multirow{3}{*}{$\begin{array}{l}\text { Harmonious relationship } \\
\text { with animals }\end{array}$} & Biology & ( ) & ( ) & ( ) & ( ) & ( ) \\
\hline & Ohers disciplines & ( ) & ( ) & ( ) & ( ) & ( ) \\
\hline & Knowledge & () & ( ) & ( ) & ( ) & $(1)$ \\
\hline \multirow{3}{*}{$\begin{array}{l}\text { Harmonious relationship } \\
\text { with plants }\end{array}$} & Biology & ( ) & ( ) & ( ) & ( ) & ( ) \\
\hline & Ohers disciplines & ( ) & ( ) & ( ) & ( ) & ( ) \\
\hline & Knowledge & $($ ) & () & () & () & $($ ) \\
\hline \multirow{3}{*}{$\begin{array}{l}\text { Diseases transmitted by } \\
\text { water }\end{array}$} & Biology & ( ) & ( ) & ( ) & ( ) & ( ) \\
\hline & Ohers disciplines & ( ) & ( ) & ( ) & ( ) & ( ) \\
\hline & Knowledge & ( ) & ( ) & ( ) & ( ) & ( ) \\
\hline
\end{tabular}

${ }^{*}$ The following alternatives were taken into account for knowledge level: 1 - No at all; 2 - Low; 3 - Moderate; 4 - Good; 5 - Very good. Source: Authors.

\section{Statistical analysis}

Results were analyzed by percentages of responses for each question alternative. Mann-Whitney's statistical test was employed for comparison between genders, with probability levels $p<0.05$ and $p<0.01$. Microsoft Excel 365 and SPSS 20.0 were employed for statistical analyses. 


\section{Ethical aspects of the research}

Current research complied to research rules with human beings, Norm $\mathrm{n}$. 466/2012, of the National Health Counci/Ministry of Health, and approved by the Committee for Ethics in Research of the Hospital Universitário Alcides Carneiro of the Federal University of Campina Grande (CEP HUAC/UFCG). All the students were informed on the relevance of their participation on signing the free consent term (TCLE).

\section{Results and Discussion}

Ages of the interviewed students $(n=90)$ ranged between 14 and 20 years, 50 were males $(55.0 \%)$ and 40 were females $(45.0 \%)$.

Table 2 show percentages for each question of the questionnaire and their levels. Students stated that the theme in which Biology most contributed for their knowledge among the environmental themes in current research comprised: Environmental Preservation. In fact, $92.5 \%$ of the students reported that Biology contributed a lot and mostly for teaching; Contaminants $(87.5 \%, \mathrm{n}=$ $79)$ and Diseases transmitted by water $(85.0 \%, n=76)$ followed.

Few students reported that Biology lacked conditions for the comprehension of environmental themes. Percentages with regard to these responses were lower than $5.0 \%$ for most questions. Students considered Biology as the discipline that had the best conditions for teaching environmental themes when it was compared to other disciplines.

The believed that other disciplines mainly contributed towards a better understanding of the following themes (responses ranged between good and very good contribution): Environmental preservation $(73.3 \%, \mathrm{n}=66)$ and Diseases transmitted by water $(69.3 \%, \mathrm{n}=62)$. Contrastingly, among themes which were researched, Harmonious relationship with animals would be that which other disciplines would have less to contribute.

The knowledge of most students on environmental themes is limited: $55.0 \%-72.5 \%$ stated that had low or no at all knowledge (Figure 1). Themes with low knowledge (not at all/low) are Solid wastes - pollution and recycling $(72.5 \%, \mathrm{n}=65)$ and Environmental preservation $(70.0 \%, \mathrm{n}=63)$.

Themes on plants and water diseases were the themes known best by students (good/very good: $14.2 \%, \mathrm{n}=13$ for both). 
Table 2: Frequency (\%) of students' opinion with regard to the contribution of Biology and other disciplines for the teaching of themes related to Environmental Education $(\mathrm{N}=90)$.

\begin{tabular}{lcccccc}
\hline \multirow{2}{*}{$\begin{array}{c}\text { Environmental } \\
\text { themes }\end{array}$} & Discipline & \multicolumn{5}{c}{ Level of contribution to knowledge } \\
\cline { 3 - 7 } & & $\begin{array}{c}\text { Very } \\
\text { good }\end{array}$ & Good & Moderate & Low & Not at all \\
\hline \multirow{2}{*}{ Water pollution } & Biology & 51,7 & 34,2 & 10,8 & 2,5 & 0,8 \\
& Ohers & 17,5 & 51,7 & 23,3 & 5,0 & 2,5 \\
\hline \multirow{2}{*}{ Soil pollution } & Biology & 50,0 & 32,5 & 11,7 & 1,7 & 4,2 \\
& Ohers & 19,2 & 45,8 & 25,0 & 7,5 & 2,5 \\
\hline \multirow{2}{*}{ Air pollution } & Biology & 47,5 & 33,3 & 15,0 & 3,3 & 0,8 \\
& Ohers & 18,3 & 42,5 & 26,7 & 10,0 & 2,5 \\
\hline \multirow{2}{*}{ Contaminants } & Biology & 57,5 & 30,0 & 9,2 & 0,8 & 2,5 \\
& Ohers & 19,2 & 44,2 & 27,5 & 5,8 & 3,3 \\
\hline Environmental & Biology & 60,8 & 31,7 & 6,7 & 0,8 & 0,0 \\
preservation & Ohers & 25,8 & 47,5 & 15,8 & 9,2 & 1,7 \\
\hline Solid waste - pollution & Biology & 51,7 & 33,3 & 8,3 & 4,2 & 2,5 \\
and recycling & Ohers & 20,8 & 48,3 & 22,5 & 4,2 & 4,2 \\
\hline Harmonious relationship & Biology & 50,0 & 29,2 & 14,2 & 3,3 & 3,3 \\
with animals & Ohers & 13,3 & 39,2 & 26,7 & 12,5 & 8,3 \\
\hline Harmonious relationship & Biology & 60,0 & 24,2 & 9,2 & 5,0 & 1,7 \\
with plants & Ohers & 14,2 & 40,8 & 30,8 & 8,3 & 5,8 \\
\hline Diseases transmitted by & Biology & 63,3 & 21,7 & 10,8 & 3,3 & 0,8 \\
water & Ohers & 21,7 & 47,5 & 20,8 & 5,8 & 4,2 \\
\hline Source: Auuthors. & & & & & &
\end{tabular}

Source: Authors.

There was significant difference in knowledge level among environmental themes evaluated with regard to gender for three environmental themes: Environmental Preservation $\left(Z_{\text {calc }}=2.54, Z_{\text {crit }}=1.96, p<0.05\right)$, Harmonious Relationship with Plants $\left(Z_{\text {calc }}=2.42, Z_{\text {crit }}=1.96, p<0.05\right)$ and Diseases transmitted by water $\left(Z_{c a l c}=2.16, Z_{\text {crit }}=1.96, p<0.05\right)$. For these three themes, males had a better knowledge (Figure 2).

Results showed that students perceived that other disciplines had a lower capacity for the teaching of themes directly involved in living beings, such as plants and animals. They also perceived that other disciplines were not exempt from the commitment in dealing with the subject.

Students, however, expected that Biology would give a greater attention in the inclusion of themes in the discipline's contents, especially through teachers' activities. All disciplines should forward environmental issues within school contents. In fact, teachers have some difficulties to these necessary changes. It should be emphasized that the school is a basic working space to provide the formation of citizenship even though it has a degraded structure (SEGURA, 2001). 


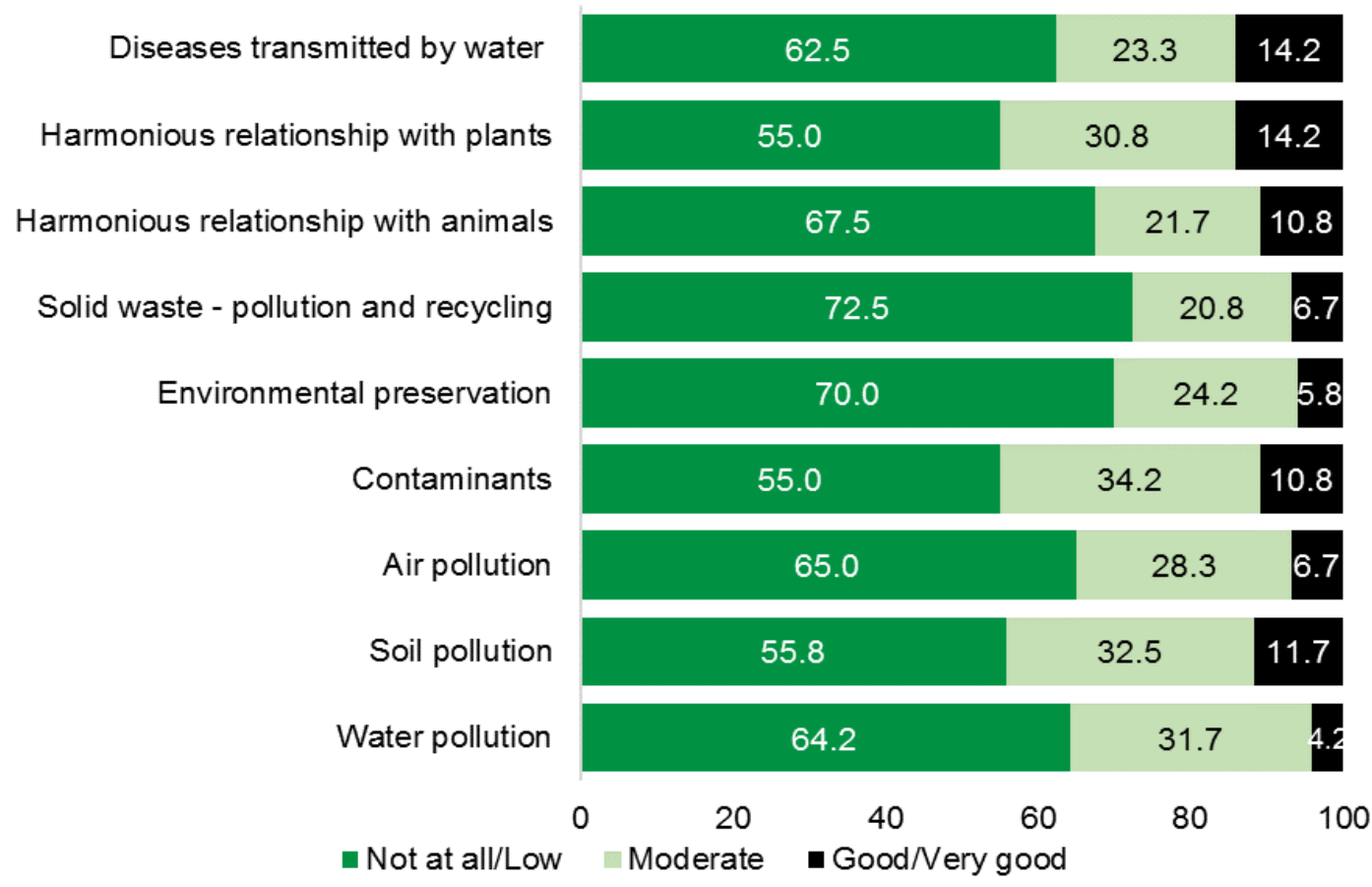

Figure 1: Percentage frequency of students on environmental themes $(N=90)$.

Source: Authors.

Although Environmental Education must be included in Basic Education in all disciplines, it is normally taught in the disciplines of Science and Biology. Such association may be historically explained due to disciplines with contents related to Environment and Ecology.

In spite of such impression by students in current research, the PCN (1999) determines that Environmental Education should be inserted in the pedagogical curriculum of all disciplines through transversal themes.

Transversality is related to learning with real things (GONZÁLESGAUDIANO, 2005). Transversality provides a wide understanding of different objects of knowledge and the perception of the implications of their activities in the environment. It opens the way for the inclusion of extra-school knowledge, providing meaning to students' experience. Therefore, transversal themes provide a social meaning to procedures and to conventional concepts, overcoming the idea of just being promoted in school (BRASIL, 1998, p. 30). 

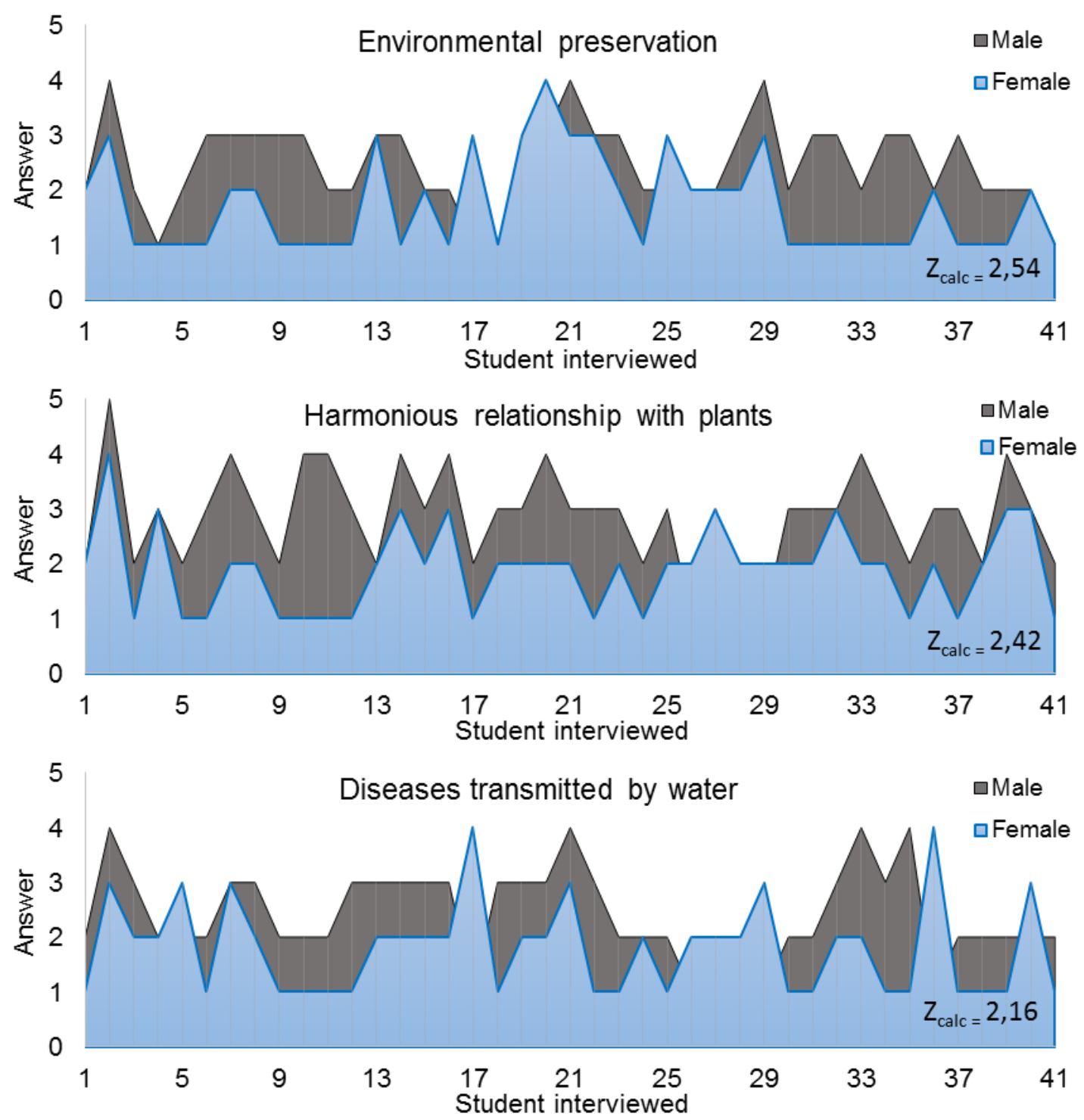

Figure 2: Variation in responses (Likert Scale: responses from Level 1 to 5 ) for environmental themes with significant difference $(p<0.05)$ between females and males $(N=90$, with 41 students of each gender). Source: Authors.

$Z_{\text {calc }}$ was registered by Mann-Whitney's test to determine significant differences between the genders when individual responses were taken into account. $Z_{\text {crit }}$ rate was 1.96 for all.

A current aspect in transversality in the teaching of Biology in Brazil is that Biology gives priority to concepts, language and methodology within this field of knowledge and makes learning only slightly efficient for the interpretation of and the intervention on day-to-day reality (BORGES and LIMA, 2007).

So that the Environment theme should be studied efficiently in the school, one should know the environment in which one lives, such as the rivers, the fauna and flora in the region. Consequently, the issues and solutions linked to the theme may be analyzed. 
However, Biology teachers should not merely work with information and theoretical concepts so that they become environmental educators. It is important that transversality becomes a tool so that the students may learn dynamically the manner of transforming the reality in which they live.

According to Berna (2004, p.30):

The environmental educator should place the students in educational situations, such as within environmental aggression or environmental conservation conditions and indicates means to understand the environmental situation. In environmental terms, the above is not difficult since we are surrounded by the environment. Environmental Education is useless when dissociated with such reality. However, the use of the environment as a motive is much more important that providing information on a river or an ecosystem in the region.

Teaching Environmental Education in the classroom should demonstrate to students its importance in the environmental context. They should be aware that they may be transforming agents and change the surrounding conditions. The transforming condition will go to other situations with the union of parts as a whole.

According to Araújo; França (2013, p. 3):

Education which is committed to the social and environmental situation is a social practice that requires a set of activities for sustainability. One of the aims is the contribution towards the humanization and emancipation of people and the formation of critical citizens.

Environmental Education contributes towards the formation of citizens' awareness with regard to their environmental responsibility, prepared to decide and act within the social and environmental medium and committed to the wellbeing of society and of all.

Students must be educated to be social agents with an ethical and critical stance on the exploration of nature and current social and environmental aspects (ARAUJO; FRANÇA, 2013).

It may be perceived that theoretically the insertion of environmental themes within a planned and clear proposal to educate students within an environmental stance is still insufficient and limited. This is why approximately one third of the interviewees had little and moderate knowledge for environmental themes.

Several motives are involved. Although an approach towards environmental themes has been gradually inserted within society and in certain educational situations for several years, official Brazilian documents have been 
available in mid-1990s when several public policies were prepared to promote and enhance Environmental Education (LAMOSA; LOREIRO, 2011).

The Brazilian Ministry of Education (MEC) published the PCN in 1999 within the context of the National Policy of Environmental Education (PNEA). The actual incorporation of issues ruled by official documents within the school environment has occurred rather slowly.

A difficulty faced by teachers is their capacity in dealing with Environmental Education since teachers who graduated up to the 1990s did not receive Environmental Education. It was not included at all levels, even in Higher Education.

Although PNEA (1999) makes it mandatory that teachers should receive complementary formation in their discipline to attend adequately to the compliance of the PNEA principles and aims, such capacity has not been complied with adequately (SILVA et al., 2015).

The watershed is the preparation of professionals for the exercise of their profession. It is the right and duty of teachers to struggle for better means in the exercise of their profession (KRASILCHIK, 2008) and to be better prepared to cope with the pedagogical challenge of the school (DEMO, 2007).

Teachers' competence in dealing with themes related to Environmental Education in the classroom is indispensible for the formation of more sensitive citizens aware of their responsibility on this theme.

According to Guimarães and Inforsato (2012), getting over the environmental crisis and compartment knowledge passes, among other things, through the environmental formation of professionals, so that their activities may intervene on the environment. Teachers' socio-environmental qualification is mandatory so that they would become socio-environmental agents and mediators for their students.

The environmental dimension must be included in the curriculum in teachers' formation at all levels and in all discipline. A specific discipline should be included in post-graduate and extension courses and in the areas on the methodological aspects of Environmental Education (BRASIL, 1999).

Government-run Higher Education institutions in the state of Paraíba, Brazil, provide several post-graduate courses (Master's and Doctoral) with disciplines or research focused on Environmental Education (VASCONCELOS; SILVA, 2015). It is highly important that such capacitation is possible for teachers of public schools with regard to viability, incentives and better valorization for qualification.

Another aspect that makes difficult the development of Environmental Education in the teaching of Biology is the restriction to exposition lessons, with a low participation of students in the learning process. Consequently, the process of cognitive development, one of the main aims in education, is compromised since there is no relationship between teaching and the students' 
experience and milieu. Teaching is thus unbounded from the day-to-day life of the student, with low efficient scientific education (KRASILCHIK, 2008).

The teacher may adopt simple procedures, with students' effective participation, to improve the methodological aspect in the teaching of Biology applied to Environmental Education (BRASIL, 2006). School curriculum for Biology should be reconsidered with regard to traditionally accepted functions. According to Libânio (2007), the school should be committed in reducing the distance between a more complex science and culture produced in day-to-day activities and given within the school milieu.

\section{Conclusions}

Interviewed students perceived that Biology, among other disciples, was the discipline with the best conditions to teach environmental themes evaluated in current research. The students reported that they had better knowledge on Solid wastes - pollution and recycling and Environmental preservation among the other nine environmental themes. Significant variation in knowledge could be seen between the genders with regard to three themes (Environmental Preservation, Harmonious relationship with plants and Diseases transmitted by water), in which males had a better knowledge.

Results reveal the need to insert Environmental Education within a planned, continuous and interdisciplinary stance so that students should have a better knowledge on the themes.

\section{References}

ARAUJO, M.L.F., FRANCA, T.L. Concepções de Educação Ambiental de professores de biologia em formação nas universidades públicas federais do Recife. Educação em Revista, v. 50, p. 237-252. 2013.

BENETTI, B.A. Temática ambiental e a perspectiva do professor de ciências. Dissertação (Mestrado em Educação) - Faculdade de Filosofia e Ciências, Universidade Estadual Paulista, Marília, São Paulo. 1998.

BERNA, V. Como fazer Educação Ambiental. 2. ed. São Paulo: Paulus. 2004.

BORGES, M.D., ARANHA, J.M., SABINO, J. A fotografia de natureza como instrumento para Educação Ambiental. Ciência e Educação (Bauru), v. 16, n. 1, p. 149-161, 2010.

BORGES, R.M.R.; LIMA, V.M.R. Tendências contemporâneas do ensino de Biologia no Brasil. Revista Electrónica de Enseñanza de las Ciências, v.6, n. 1, p. 165-175, 2007. 
BRASIL. Secretaria da Educação Fundamental. Parâmetros Curriculares Nacionais: terceiro e quarto ciclos: apresentação dos temas transversais. Secretaria de Educação Fundamental. Brasília: MEC/SEF, 1998. Available in: $<$ portal.mec.gov.br/seb/arquivos/pdf/ttransversais.pdf $>$. Accessed December 8, 2014.

BRASIL. Lei no 9.795 de 27 de abril de 1999, dispõe sobre a Educação Ambiental, institui a Política Nacional Educação Ambiental. 1999. Available in: $<$ www.planalto.gov.br/ccivil 03/leis/19795.htm>. Accessed December 8, 2014.

CARVALHO, L.M. A temática ambiental e a escola de $1^{\circ}$ grau. Tese (Doutorado em Educação) - Faculdade de Educação, Universidade de São Paulo - USP, São Paulo. 1989.

DEMO, P. Os desafios modernos da educação. 14 $4^{\underline{a}}$ ed. Petrópolis: Vozes. 2007.

GONZÁLES-GAUDIANO, E. Interdisciplinaridade e Educação Ambiental: explorando novos territórios epistêmicos. In: SATO, M.; CARVALHO, I.M. Educação Ambiental: pesquisa e desafios. Porto Alegre: Artmed. 2005.

GUIMARAES, S.S.M., INFORSATO, E.C. A percepção do professor de Biologia e a sua formação: a Educação Ambiental em questão. Ciência e Educação (Bauru), v. 18, n. 3, p. 737-754, 2012.

IARED, V.G., OLIVEIRA, H.T. Concepções de Educação Ambiental e perspectivas pedagógicas de professoras do ensino fundamental. Educação em Revista, v. 27, n. 2, p. 95-122, 2011.

KRASILCHIK, M. Prática de Ensino de Biologia. $4^{a}$ ed. São Paulo: Editora da USP. 2008.

LAMOSA, R.A.C., LOUREIRO, C.F.B. A Educação Ambiental e as políticas educacionais: um estudo nas escolas públicas de Teresópolis (RJ). Educação e Pesquisa, v. 37, n. 2, p. 279-292, 2011.

LIBÂNEO, J.C. Adeus professor, adeus professora? Novas exigências educacionais e profissão docente. 10ª ed. São Paulo: Cortez. 2007.

LUCKESI, C.C. Por uma prática docente crítica e construtiva. In: LUCKESI, C.C. (org.). Avaliação da aprendizagem escolar: estudos e proposições. Cap. VII. 9. ed. São Paulo: Cortez, p. 7-180. 1999.

SAUVÉ, L. (2005). Educação Ambiental: possibilidades e limitações. Educação e Pesquisa, São Paulo, v. 31, n. 2, p. 317-32, 2005.

SEGURA, D.S.B. Educação Ambiental na escola Pública: da curiosidade ingênua à consciência crítica. São Paulo. Annablume: FAPESP. 2001.

SILVA, E., SILVA, F.G., SILVA, R.F.L., SILVA, R.H., OLIVEIRA, H.M. Avaliação do saber ambiental de professores do ensino público do município de São Bento, Paraíba. Scientia Plena, v. 11, n. 9, p. 1-11, 2015. 
SOARES, J. F. (2004). O efeito da escola no desempenho cognitivo de seus alunos. Revista Electrónica Iberoamericana sobre Calidad. Eficacia y Cambio em Educación, v. 2, n. 2, p. 83-104, 2004.

ROCHA, J.S.M. Manual de Projetos Ambientais. Santa Maria: UFCM. 1997.

TRAJBER, R., MENDONÇA, P. (Orgs.). Educação na diversidade: o que fazem as escolas que dizem que fazem Educação Ambiental. Brasília: Secretaria de Educação Continuada, Alfabetização e Diversidade, 2006.

VASCONCELOS, H.D.L., SILVA, E. Research in Environmental Education in the state of Paraíba, Brazil: analysis of its insertion and professors' commitment in post-graduate courses. Revista Brasileira de Educação Ambiental, v. 10, n. 2, p. 113-125, 2015. 